\title{
KAJIAN MOTIVASI DALAM UPAYA PENCAPAIAN TUJUAN PROGRAM PERTUKARAN PEMUDA INDONESIA-KANADA 2014-2015
}

\author{
Made Panji Teguh Santoso, S.IP., MM. ${ }^{1)}$ \\ ${ }^{1}$ Fakultas Ekonomi dan Bisnis, Universitas Singaperbangsa Karawang \\ email: mpt.santoso@gmail.com
}

\begin{abstract}
Youths are the hope and determining achievement factors of a country's future success. International youth exchange program, in this case Indonesia-Canada Youth Exchange Program (ICYEP) 20142015, has been one of the options taken by the two countries. Motivations of young people to join ICYEP 2014-2015 are strongly related to the achievement of ICYEP 2014-2015 objectives. Douglas McGregor's Theory $Y$ and Daniel Pink's Self-Determination Theory can be used to explain their motivations. ICYEP 2014-2015 provides ways for its participants to achieve their motivations. The motivations, in turns, ends in the achievement of the objectives of ICYEP 2014-2015 having been outlined by the Ministry of Youth and Sport of the Republic of Indonesia (Kemenpora RI) and Canada World Youth (CWY). Utilizing qualitative method, this research aims to identify participants' motivations to participate in ICYEP 2014-2015, achievements, constraints, and relations to the accomplishment of the objectives of ICYEP 2014-2015. The research results display that there are various kinds of motivations supporting research subjects' decisions to participate in ICYEP 20142015, and this program provides the right paths to attain their motivations. There are correlations between the achievement of research subjects' motivations and the accomplishment of ICYEP 20142015.
\end{abstract}

Keywords: motivations, Indonesia, Canada, youth exchange program, objectives. 


\section{PENDAHULUAN}

Manusia merupakan faktor terpenting dalam suatu organisasi. Ada banyak istilah yang kita kenal untuk mendeskripsikan betapa pentingnya manusia. Istilah sumber daya manusia, modal manusia, aset intelektual, dan manajemen bakat menyiratkan bahwasanya adalah manusia yang menjalankan kinerja organisasi-organisasi mereka, seiringan dengan sumber daya lainnya seperti finansial, material dan informasi. Organisasi-organisasi yang sukses adalah mereka yang mahir dan cakap dalam menyatukan orang-orang yang berbeda untuk mencapai tujuan bersama (Bohlander dan Snell, 2013: 4).

Setiap negara menitikberatkan pembangunan sumber daya manusia pada bidang pembinaan generasi mudanya. Negara percaya bahwa selain mengemban tugas negara di masa yang akan datang, generasi muda mempunyai energi dan kekuatan fisik yang lebih besar dibandingkan dengan para pendahulunya. Generasi muda pun mempunyai harapan hidup yang lebih panjang. Generasi muda yang kuat, rajin, pandai, berdedikasi dan aktif akan menjamin kelangsungan dan kejayaan negara di masa depan. Sebaliknya generasi muda yang lemah, malas, bodoh, tidak acuh dan pasif sudah barang tentu akan membawa masa depan yang suram kepada suatu negara.

Di Indonesia pembangunan sumber daya manusia muda dipayungi oleh Undang-Undang No. 40 tahun 2009 tentang Kepemudaan, yang berdasarkan pada Pasal 5 ayat (1), Pasal 20, Pasal 27, Pasal 28C, Pasal 31 ayat (1), ayat (4), dan ayat (5) Undang-Undang Dasar Negara Republik Indonesia tahun 1945. Negara Indonesia mengerti bahwa harus ada programprogram kegiatan untuk menyadarkan dan memberdayakan generasi mudanya. Menurut UU 40/2009 tentang Kepemudaan ini, penyadaran pemuda adalah kegiatan yang diarahkan untuk memahami dan menyikapi perubahan lingkungan (Pasal 1 ayat 5). Pemberdayaan pemuda adalah kegiatan membangkitkan potensi dan peran aktif pemuda (Pasal 1 ayat 6). Pemerintah Indonesia sadar bahwa untuk membangun generasi mudanya dibutuhkan segala upaya untuk mencapai hasil yang optimal. Salah satu cara untuk mencapai hasil terbaik adalah dengan membangun kemitraan atau partnership dengan pihak manapun yang mempunyai kepentingan dan keinginan yang sama. Kemitraan ini dijamin oleh UU 40/2009 ini, di mana di situ tertulis bahwasanya kemitraan adalah kerja sama untuk membangun potensi pemuda dengan prinsip saling membutuhkan, saling memperkuat, dan saling melengkapi.
Kemitraan yang dimaksud di sini adalah kemitraan berbasis program dalam pelayanan kepemudaan yang dilakukan dengan memperhatikan prinsip kesetaraan, akuntabilitas, dan saling memberi manfaat (Pasal 32 ayat 1 dan 2). Kemitraan yang dimaksud di sini dapat dilakukan pada tingkat lokal, nasional, dan internasional (Pasal 32 ayat 3).

Kanada memiliki populasi generasi muda yang terus berkembang, kurang lebih bertambah sekitar 3\% setiap tahunnya. Tidak ada otoritas nasional yang mempunyai mandat untuk generasi muda. Namun demikian ada beberapa badan yang memiliki tanggung jawab yang jelas atas generasi muda dalam hubungannya dengan keadilan dan kejahatan, pekerjaan dan kesehatan di seluruh provinsi dan teritori dalam negara Kanada (Anonim ${ }^{1}$, 2014). Beberapa organisasi di sektor publik dan swasta berkontribusi kepada generasi muda, membantu mereka untuk menjadi warga negara yang lebih aktif dan bertanggung jawab, sekaligus meraih ketrampilan untuk menjadi inovator, pencipta, seniman, dan jurumudi ekonomi Kanada di masa depan. Lewat Departemen Warisan Kanada, pemerintah Kanada menyediakan dana lebih dari 80 juta dolar Kanada setiap tahunnya untuk programprogram generasi muda dan kegiatan-kegiatan yang menjangkau ratusan ribu pemuda Kanada (Anonim ${ }^{2}$, 2014). Walaupun sebagian program kepemudaan itu terdesentralisasi di tingkat provinsi/kabupaten atau dilaksanakan oleh organisasi non pemerintah dan masyarakat madani, bukan berarti pemerintah federal Kanada lepas tangan atas pembangunan generasi mudanya. Lewat badan-badan resminya, seperti Layanan untuk Pemuda dan Layanan Kanada, mereka membantu untuk memberikan informasi kepada para generasi muda Kanada tentang program-program yang dapat mereka akses dalam rangka pengembangan potensi diri mereka (Anonim ${ }^{3}$, 2014 dan Anonim 4 , 2014). Program-program pembangunan yang ditawarkan kepada para pemuda Kanada ada bermacam-macam, meliputi pendanaan studi, pelatihan dan magang kerja, tabungan berjangka, beasiswa, fokus karir, kerja paruh atau penuh waktu, bimbingan dan sponsor penelitian, sampai ke pertukaran pemuda (Anonim ${ }^{3}$, 2014).

Berdasarkan pembahasan di atas, pemerintah Indonesia dan pemerintah Kanada sama-sama memandang penting pembinaan generasi mudanya. Mereka melihat adanya kesempatan untuk membentuk kerjasama dalam bentuk program pertukaran pemuda antarnegara. Pemerintah Indonesia melihat program kerjasama ini sebagai usaha untuk mewujudkan kemitraan dengan negara lain 
yang mempunyai kepentingan dan keinginan yang sama, yaitu membangun generasi mudanya dengan prinsip saling membutuhkan, saling memperkuat, dan saling melengkapi. Sedangkan Kanada melihat program pertukaran pemuda ini sebagai salah satu pilihan program pembangunan pemuda yang dapat ditawarkan kepada generasi mudanya.

Mengikuti program pertukaran pemuda membawa banyak manfaat bagi para pesertanya. Mereka dapat:

1. Meningkatkan kemampuan untuk terlibat dalam proses pembelajaran yang mandiri dan reflektif;

2. Membangun ketrampilan berbahasa dan berkomunikasi yang efektif;

3. Memperluas pemahaman dan penghargaan kepada keanekaragaman dan kebudayaan lain;

4. Memiliki kesempatan untuk ikut serta dalam jejaring internasional, di mana mereka bisa bertemu orang-orang dari latar belakang budaya dan perspektif profesional yang berbeda;

5. Mempunyai kesempatan untuk memaksimalkan pembangunan pribadi, termasuk kepercayaan diri dan kemandirian;

6. Mendapatkan rasa hormat atas praktik etis dan tanggung jawab sosial;

7. Mendapatkan posisi kompetitif dalam ketenagakerjaan internasional;

8. Memperkuat kapasitas dalam berpikir analitis dan kritis;

9. Melibatkan diri dalam kerja kolaboratif dan multidisipliner, yang bisa memperkuat ketrampilan yang penting dalam kehidupan mereka sebagai seorang profesional kelak;

10. Mendapatkan akses ke jenjang pendidikan lebih lanjut yang ditawarkan oleh institusi luar negeri. (UNSW, 2014: 3)

Berdasarkan latar belakang yang telah diuraikan, maka perumusan masalah dalam penelitian ini adalah sebagai berikut:

1. Bagaimana motivasi pribadi para peserta dalam mengikuti Program Pertukaran Pemuda Indonesia-Kanada (PPIK) 20142015?

2. Bagaimana pencapaian motivasi para peserta PPIK 2014-2015?

3. Faktor-faktor apa yang menyebabkan tidak tercapainya motivasi pribadi para peserta dan tujuan-tujuan PPIK 2014-2015?

4. Bagaimana kaitan motivasi pribadi para peserta dengan pencapai tujuan-tujuan PPIK 2014-2015?

\section{KAJIAN PUSTAKA}

Mondy mengatakan bahwa manajemen sumber daya manusia (MSDM) adalah pemanfaatan para individu untuk mencapai tujuan-tujuan organisasi. Konsekuensinya, para manajer di setiap tingkat harus melibatkan diri mereka dengan manajemen sumber daya manusia (Mondy, 2008: 4). Hal ini berarti semua orang yang ada di setiap lini manajerial negeri ini harus memikirkan bagaimana mereka dapat memainkan peranan mereka dalam pembangunan sumber daya manusia.

Motivasi dapat dijelaskan sebagai suatu dasar pendorong atau perangsang yang menyebabkan orang akan berbuat sesuatu, dan motivasi ini merupakan penuntun kekuatan yang menggerakkan manusia untuk bertingkah laku untuk mencapai tujuan tertentu. Selain itu, motivasi juga merupakan suatu proses untuk mencoba mempengaruhi agar seseorang dapat melakukan sesuatu yang kita inginkan. (Handoko, 2003: 231)

Dalam bukunya Human Behavior in Organization, McGregor (1960) menekankan pendekatan penciptaan lingkungan di mana karyawan suatu perusahaan akan termotivasi lewat otoritas, arah dan kontrol atau integrasi dan kontrol diri. McGregor dalam Teori Y berpendapat bahwa manajemen berasumsi bahwa para karyawan bisa jadi ambisius, mempunyai motivasi diri, serta melatih kontrol diri. Manajemen memercayai bahwa para karyawan menikmati tugas-tugas fisik dan mental mereka. Menurut mereka, pekerjaan itu sangat alamiah. Orang-orang ini sebenarnya memiliki kemampuan menyelesaikan masalah secara kreatif, namun bakat-bakat mereka tidak terlalu dipakai dalam organisasi kebanyakan. Dengan kondisi seperti ini, manajer teori $\mathrm{Y}$ percaya bahwa para karyawan akan belajar untuk secara aktif mencari dan menerima tanggung jawab untuk melatih kontrol diri dan arahan diri dalam mencapai tujuan-tujuan sesuai dengan komitmen mereka. (Anonim ${ }^{5}$, 2014) Seorang manajer pendukung teori $Y$ percaya bahwa, bila diberikan kondisi yang tepat, sebagian besar orang akan berusaha untuk memberikan yang terbaik dalam bekerja. Mereka percaya bahwa kepuasan dalam melakukan pekerjaan adalah sebuah motivasi yang kuat. Banyak orang menginterpretasikan Teori Y sebagai sebuah kepercayaan yang positif tentang karyawan.

Pink melalui SDT yang ditulisnya dalam buku Drive, the Surprising Truth about What Motivates Us menawarkan ide bahwa manusia sejatinya mempunyai dorongan-dorongan dari 
sejak lahir untuk menjadi mandiri, ulet dan terhubung dengan manusia yang lain. Bila dorongan-dorongan ini terus dipelihara dan dikembangkan, maka manusia akan mendapatkan lebih dan akan hidup dalam keadaan yang lebih kaya. (Pink, 2009: 48-56). Perusahaan-perusahaan, termasuk di dalamnya negara, seharusnya memfokuskan diri pada dorongan-dorongan ini dalam mengelola sumber daya manusia dalam menciptakan keadaan-keadaan yang memusatkan perhatian pada kebutuhan sejak lahir untuk mengarahkan hidupnya sendiri, untuk belajar dan menciptakan hal-hal baru, dan untuk melakukan hal-hal yang lebih baik oleh dirinya sendiri dan dunia kita.

Penelitian yang akan dilakukan harus dilandasi oleh kerangka pemikiran. Kerangka pemikiran dan kerangka konsep merupakan bagian yang sama yang berkaitan dengan kerangka teori. Kerangka konsep adalah merupakan suatu kristalisasi dari kumpulan teori dan pandangan para pakar serta pandangan peneliti yang memberikan jawaban, gambaran serta ulasan terhadap berbagai masalah dari suatu fenomena yang diangkat dari suatu penelitian.

Model penelitian ini dapat digambarkan sebagai berikut:

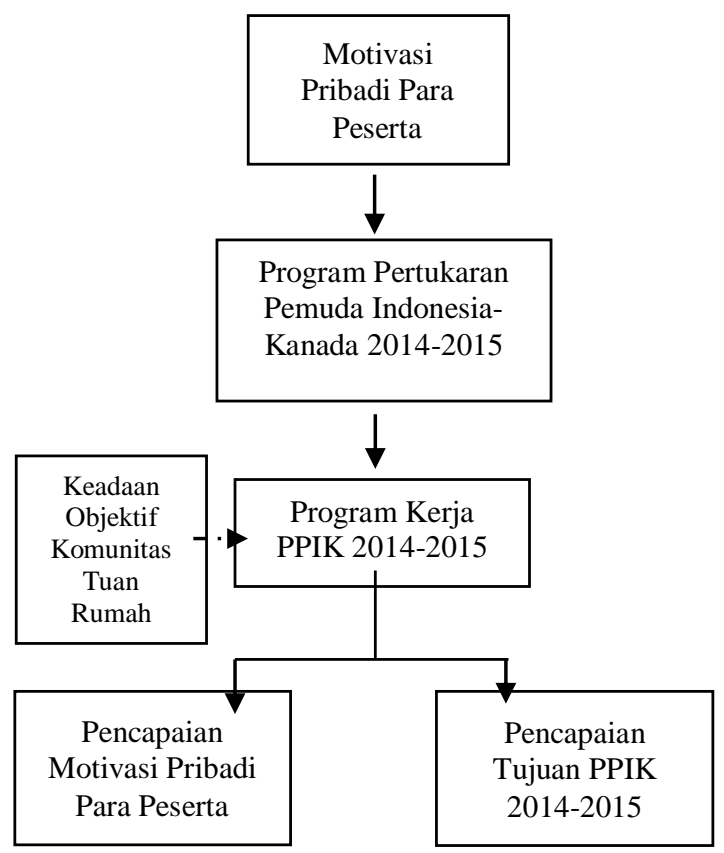

Gambar 1. Model Penelitian Tesis Penulis

Motivasi para peserta, dalam model penelitian ini, merupakan variabel bebas, dan PPIK 2014-2015 adalah variabel antara. Dengan program kerja sebagai variabel terikat, penelitian ini menetapkan pencapaian motivasi pribadi para peserta dan pencapaian tujuan PPIK 2014-2015 sebagai hasil akhir dari penelitian.

\section{METODE PENELITIAN}

Penelitian ini menggunakan metode penelitian kualitatif, di mana yang dimaksud dengan penelitian kualitatif adalah prosedur penelitian yang menggunakan data deskriptif berupa kata-kata tertulis atau lisan dari orangorang yang diwawancarai. Penelitian kualitatif meliputi kesatuan dari suatu penafsiran untuk menggambarkan, memecahkan kode, menerjemahkan dan memberikan makna, bukan dalam bentuk frekuensi tertentu yang menunjukkan kurang atau lebih terhadap terjadinya gejala alami dalam lingkup kehidupan sosial.

Dalam berbagai macam penelitian, tidak semua hasil observasi atau pengukuran itu berupa angka. Terdapat data seperti "puas", "rusak", "gagal", "berhasil", "berprestasi" dan lain sebagainya. Data inilah yang disebut sebagai data kualitatif (Silalahi, 2012: 284).

Bogdan dan Taylor yang dikutip oleh Andi Prastowo menyatakan bahwa dasar pertimbangan yang bisa dijadikan argumen untuk menggunakan metode kualitatif adalah:

1. Masalah yang diteliti mengarah kepada keadaan-keadaan dari individu secara holistik (utuh). Pokok kajiannya tidak akan diredusir (disederhanakan) kepada variabel yang telah ditata atau sebuah hipotesis yang telah direncanakan sebelumnya, namun akan dilihat sebagai suatu bagian yang utuh.

2. Penelitian bertujuan untuk memahami masyarakat secara personal dan memandang mereka sebagaimana mereka sendiri mengungkapkan pandangan dunianya.

3. Penelitian bertujuan untuk membuat dan menyusun konsep - konsep yang hakiki, seperti indah, menderita, kenyakinan, penderitaan, frustasi, harapan, cinta dan lain sebagainya. (Prastowo, 2012: 179)

Sebagai suatu penelitian kualitatif yang lain, penelitian studi kasus ini menggunakan berbagai sumber data atau Studi Kasus Berganda. Dalam penelitian kualitatif, pengggunaan berbagai sumber data dimaksudkan untuk mendapatkan data yang terperinci dan komprehensif yang menyangkut obyek yang diteliti. Disamping itu, hal tersebut juga dimaksudkan untuk mencapai validitas dan realibilitas penelitian. Dengan adanya berbagai sumber data tersebut, peneliti dapat meyakinkan kebenaran dan keakuratan data yang diperolehnya dengan mengecek salingsilangkan antar data yang diperoleh. 
Prosedur dari penelitian merupakan alat yang menjadi penuntun maupun cara-cara yang dilakukan dalam penelitian. Hal-hal yang menjadi dasar dalam pengumpulan data, analisis data, interpretasi data, menerjemahkan data dan menyimpulkan data yang didapatkan dari lapangan secara benar dan sesuai dengan aturan. Penelitian ini ingin melihat pengaruh motivasi pribadi para peserta dan keadaan objektif komunitas tuan rumah terhadap program kerja dan implikasinya dalam pencapaian tujuan Program Pertukaran Pemuda Indonesia-Kanada 2014-2015 di mana ini merupakan studi Program Pertukaran Pemuda Pertukaran Pemuda Indonesia-Kanada di Kelurahan Pulau Tidung Kepulauan Seribu DKI Jakarta.

Parameter dalam penelitian masih bersifat umum sehingga diperlukan definisi terhadap paramater tersebut. Paramater didefenisikan secara operasional agar ditemukan dimensi yang dapat dijabarkan. Dalam penelitian ini maka yang menjadi parameter utama adalah motivasi para peserta untuk mengikuti PPIK.

Meminjam teori Y dari Douglas McGregor di sini para peserta diidentikkan dengan para karyawan. Diasumsikan bahwa para peserta PPIK itu bisa jadi ambisius, mempunyai motivasi diri, serta melatih kontrol diri. Dipercayai bahwa para peserta PPIK menikmati tugas-tugas fisik dan mental mereka. Menurut mereka, pekerjaan itu sangat alamiah. Para peserta PPIK ini sebenarnya memiliki kemampuan menyelesaikan masalah secara kreatif, namun bakat-bakat mereka tidak terlalu dipakai dalam organisasi kebanyakan. Dengan kondisi seperti ini, teori $\mathrm{Y}$ percaya bahwa para peserta akan belajar untuk secara aktif mencari dan menerima tanggung jawab untuk melatih kontrol diri dan arahan diri dalam mencapai tujuan-tujuan sesuai dengan komitmen mereka. (Anonim ${ }^{5}, 2014$ )

Sebagai pendukung teori $\mathrm{Y}$ penulis percaya bahwa, bila diberikan kondisi yang tepat, sebagian besar orang akan berusaha untuk memberikan yang terbaik dalam bekerja.

Penelitian kualitatif memilki pedoman tentang bagaimana memilih unit analisis atau sasaran yang tepat sesuai masalah penelitian. Pemilihan unit analisis/subjek dalam penelitian kualitatif terkesan kurang berstruktur dan tidak sistematis jika dibandingkan dengan penelitian kuantitatif. Pada penelitian kualitatif, tidak digunakan istilah sampel, melainkan subjek/reponden/partisipan. Fokus penelitian kualitatif adalah pada kedalaman dan proses sehingga cenderung dilakukan dengan jumlah kasus sedikit (Poerwandari, 2011: 56).
Penelitian kualitatif berusaha untuk terus mencari unit-unit dan data-data baru yang relevan dengan topik penelitian. Pengambilan data akan mengarah kepada pemilihan subjek. Pemilihan subjek nantinya akan mengarahkan peneliti pada data yang semakin spesifik dalam menjawab masalah penelitian (Poerwandari, 2011: 57).

Sebelum sebuah penelitian dimulai, maka sudah harus dimiliki pedoman yang akan dilibatkan dalam topik, orang yang akan diwawancarai, baik subjek maupun narasumber, dan juga karakteristik subjek.

Unit analisis atau subjek penelitian ini adalah tiga dari delapan belas peserta PPIK 2014-2015 yang ditempatkan di Kelurahan Pulau Tidung Kecamatan Kepulauan Seribu Selatan Kabupaten Administrasi Kepulauan Seribu Provinsi Daerah Khusus Ibukota Jakarta. Jumlah subjek yang hanya sedikit ini salah satunya disebabkan oleh masalah waktu yang memang sangat terbatas. Namun, tidak menutup kemungkinan jumlah subjek akan bertambah jika kemudian ditemukan subjek lain. Penentuan subjek ini diharapkan dapat menghasilkan penelitian yang menunjukkan deskripsi yang berkualitas dan mendetail dengan tetap mendokumentasikan keunikan masing-masing kasus dan juga menunjukkan pola-pola yang tampil dari tiap-tiap subjek yang berbeda.

Karena fokus penelitian adalah tentang motivasi para peserta dalam mengikuti PPIK 2014-2015 dan keadaan objektif komunitas tuan rumah, maka yang menjadi sasaran dari penelitian ini adalah tiga dari delapan belas peserta PPIK 2014-2015 dan Kelurahan Pulau Tidung Kepulauan Seribu Selatan.

Hubungan keterkaitan antara data yang didapatkan di lapangan dengan proposisi dapat dilihat pada tabel di bawah ini.

Tabel 1. Keterkaitan Data dengan Proposisi 


\begin{tabular}{|c|c|c|c|}
\hline No & Proposisi & $\begin{array}{l}\text { Data yang } \\
\text { Relevan }\end{array}$ & $\begin{array}{c}\text { Data } \\
\text { Penghubung ke } \\
\text { Proposisi }\end{array}$ \\
\hline 1 & $\begin{array}{l}\text { Dengan } \\
\text { mengetahui } \\
\text { motivasi } \\
\text { pribadi para } \\
\text { peserta dalam } \\
\text { mengikuti } \\
\text { Program } \\
\text { Pertukaran } \\
\text { Pemuda } \\
\text { Indonesia- } \\
\text { Kanada (PPIK) } \\
\text { 2014-2015 } \\
\text { dapat diketahui } \\
\text { faktor-faktor } \\
\text { yang } \\
\text { membantu } \\
\text { pencapaian } \\
\text { tujuan-tujuan } \\
\text { PPIK 2014- } \\
\text { 2015. }\end{array}$ & $\begin{array}{l}\text { Data yang } \\
\text { menunjukkan } \\
\text { motivasi pribadi } \\
\text { para peserta } \\
\text { mengikuti PPIK } \\
\text { 2014-2015 serta } \\
\text { data yang } \\
\text { menjabarkan } \\
\text { tujuan-tujuan } \\
\text { PPIK 2014- } \\
\text { 2015. }\end{array}$ & $\begin{array}{l}\text { Data tersebut } \\
\text { menunjukkan } \\
\text { motivasi- } \\
\text { motivasi } \\
\text { pribadi para } \\
\text { peserta yang } \\
\text { membantu } \\
\text { pencapaian } \\
\text { tujuan-tujuan } \\
\text { PPIK 2014- } \\
\text { 2015. }\end{array}$ \\
\hline 2 & $\begin{array}{l}\text { Pencapaian } \\
\text { motivasi para } \\
\text { peserta PPIK } \\
2014-2015 \\
\text { berhubungan } \\
\text { dengan } \\
\text { kesuksesan } \\
\text { PPIK 2014- } \\
2015 \text {. }\end{array}$ & $\begin{array}{l}\text { Data tentang } \\
\text { pencapaian } \\
\text { motivasi } \\
\text { menggunakan } \\
\text { model Teori Y } \\
\text { dari Douglas } \\
\text { McGregor dan } \\
\text { Self- } \\
\text { Determination } \\
\text { Theorydari } \\
\text { Daniel Pink. }\end{array}$ & $\begin{array}{l}\text { Data tersebut } \\
\text { menunjukkan } \\
\text { pencapaian } \\
\text { motivasi para } \\
\text { peserta dan } \\
\text { dari situ akan } \\
\text { hubungannya } \\
\text { dengan } \\
\text { kesuksesan } \\
\text { PPIK 2014- } \\
2015 \text {. }\end{array}$ \\
\hline
\end{tabular}

Selanjutnya dapat dilihat perumusan masalah menjadi kemungkinan hasil penelitian pada tabel di bawah ini.

Tabel 2. Perumusan Masalah hingga menjadi Hasil Penelitian

\begin{tabular}{|c|c|c|c|}
\hline No. & $\begin{array}{c}\text { Perumusan } \\
\text { Masalah }\end{array}$ & $\begin{array}{c}\text { Kemungkinan } \\
\text { Temuan yang } \\
\text { Didapat dalam } \\
\text { Penelitian } \\
\end{array}$ & $\begin{array}{c}\text { Kemungkinan } \\
\text { Hasil Penelitian }\end{array}$ \\
\hline 1. & $\begin{array}{l}\text { Bagaimana } \\
\text { motivasi } \\
\text { pribadi para } \\
\text { peserta dalam } \\
\text { mengikuti } \\
\text { Program } \\
\text { Pertukaran } \\
\text { Pemuda } \\
\text { Indonesia- } \\
\text { Kanada } \\
\text { (PPIK) 2014- } \\
\text { 2015? }\end{array}$ & $\begin{array}{l}\text { Adanya data } \\
\text { yang akan } \\
\text { menunjukkan } \\
\text { apa saja } \\
\text { motivasi para } \\
\text { peserta dalam } \\
\text { mengikuti } \\
\text { PPIK 2014- } \\
\text { 2015. }\end{array}$ & $\begin{array}{l}\text { Motivasi } \\
\text { pribadi para } \\
\text { peserta dalam } \\
\text { mengikuti } \\
\text { PPIK 2014- } \\
2015 \text { memang } \\
\text { jelas terlihat. } \\
\text { Namun ada } \\
\text { kemungkinan } \\
\text { ada faktor non- } \\
\text { motivasi. }\end{array}$ \\
\hline 2. & $\begin{array}{l}\text { Bagaimana } \\
\text { pencapaian } \\
\text { motivasi para } \\
\text { peserta PPIK } \\
2014-2015 ?\end{array}$ & $\begin{array}{l}\text { Pencapaian } \\
\text { motivasi para } \\
\text { peserta PPIK } \\
\text { 2014-2015 } \\
\text { sangat } \\
\text { beraneka } \\
\text { ragam. }\end{array}$ & $\begin{array}{l}\text { Beberapa } \\
\text { peserta berhasil } \\
\text { mencapai } \\
\text { semua } \\
\text { motivasinya, } \\
\text { sementara yang } \\
\text { lainnya } \\
\text { mungkin hanya } \\
\text { mencapai } \\
\text { sebagiannya } \\
\text { saja. }\end{array}$ \\
\hline 3. & $\begin{array}{l}\text { Faktor-faktor } \\
\text { apa yang } \\
\text { menyebabkan } \\
\text { motivasi } \\
\text { pribadi para } \\
\text { peserta dan } \\
\text { tujuan-tujuan } \\
\text { PPIK 2014- } \\
2015 \text { belum } \\
\text { tercapai? }\end{array}$ & $\begin{array}{l}\text { a. Profil } \\
\text { pribadi } \\
\text { peserta } \\
\text { PPIK 2014- } \\
2015 \text { yang } \\
\text { beraneka } \\
\text { ragam; } \\
\text { b. Profil } \\
\text { kelompok } \\
\text { PPIK 2014- } \\
\text { 2015 yang } \\
\text { unik; } \\
\text { Kondisi } \\
\text { geografi dan } \\
\text { demografi } \\
\text { Kelurahan } \\
\text { Pulau } \\
\text { Tidung yang } \\
\text { menarik. }\end{array}$ & $\begin{array}{l}\text { Profil pribadi } \\
\text { para peserta, } \\
\text { profil } \\
\text { kelompok } \\
\text { PPIK 2014- } \\
2015 \text {, serta } \\
\text { kondisi } \\
\text { geografi dan } \\
\text { demografi } \\
\text { Kelurahan } \\
\text { Pulau Tidung } \\
\text { berhubungan } \\
\text { dengan belum } \\
\text { tercapainya } \\
\text { motivasi } \\
\text { pribadi para } \\
\text { peserta dan } \\
\text { tujuan-tujuan } \\
\text { PPIK 2014- } \\
\text { 2015. }\end{array}$ \\
\hline 4. & $\begin{array}{l}\text { Bagaimana } \\
\text { kaitan } \\
\text { motivasi } \\
\text { pribadi para } \\
\text { peserta } \\
\text { dengan } \\
\text { pencapaian } \\
\text { tujuan-tujuan } \\
\text { PPIK 2014- } \\
\text { 2015? }\end{array}$ & $\begin{array}{lr}\text { Data tentang } \\
\text { motivasi } \\
\text { pribadi para } \\
\text { peserta yang } \\
\text { sejalan dengan } \\
\text { data tentang } \\
\text { tujuan-tujuan } \\
\text { PPIK 2014- } \\
\text { 2015. }\end{array}$ & $\begin{array}{l}\text { Motivasi } \\
\text { pribadi para } \\
\text { peserta } \\
\text { berkaitan erat } \\
\text { dengan } \\
\text { pencapaian } \\
\text { tujuan-tujuan } \\
\text { PPIK 2014- } \\
2015 \text {. }\end{array}$ \\
\hline
\end{tabular}

Sumber : Data Primer Diolah. 2015.

Mengingat metode penelitian yang dipakai adalah metode penelitian kualitatif, maka jenis dan sumber data tersebut dapat berupa catatan hasil wawancara, pengamatan lapangan, pengamatan artefak dan dokumen. 
Diungkapkan oleh Pohan dalam Prastowo (2012: 204) bahwa data itu adalah fakta, informasi atau keterangan. Keterangan yang merupakan bahan baku dalam penelitian untuk dijadikan bahan pemecahan masalah atau bahan untuk mengungkapkan suatu gejala. Maka dalam pelaksanaan penelitian data merupakan dasar untuk dapat ditemukan pemecahan berbagai permasalahan yang menjadi objek penelitian.

Menurut Lofland dan Lofland dalam Lexy Moleong (2012: 157) bahwa sumber data utama dalam penelitian kualitatif adalah katakata dan tindakan, selebihnya adalah data tambahan seperti dokumen dan lain-lain. Penelitian ini dilakukan di Kelurahan Pulau Tidung Kecamatan Kepulauan Seribu Selatan Kabupaten Administrasi Kepulauan Seribu dan internet. Jenis data yang digunakan yaitu data primer dan data sekunder.

Data primer merupakan data yang diambil secara langsung, data primer yang diperoleh dari:

1. Wawancara dengan beberapa peserta PPIK 2014-2015di tempat pelaksanaan fase Indonesia, yaitu di Kelurahan Pulau Tidung secara tatap muka;

2. Wawancara dengan staf lapangan, yaitu Project Supervisor PPIK 2014-2015 secara tatap muka.

3. Observasi dan pencatatan kondisi hasil proyek PPIK 2014-2015 di Kelurahan Pulau Tidung;

4. Dokumentasi kondisi desa.

Data sekunder dalam penelitian ini diambil dari:

1. Data statistik Indonesia dan Kanada di internet;

2. Kementerian Pemuda dan Olahraga Republik Indonesia di Jakarta;

3. Data profil Kelurahan Pulau Tidung.

Teknik pengumpulan data pada metode kualitatif menurut Hamidi (2010: 56) adalah wawancara mendalam (in-depth, intensive interview), teknik observasi, dan teknik dokumentasi. Wawancara adalah percakapan dengan maksud tertentu. Maksud digunakannya wawancara antara lain adalah sebagai berikut :

1. Mengkonstruksi mengenai orang, kejadian, kegiatan organisasi, perasaan, motivasi, tuntutan, kepedulian dan lain-lain;

2. Mengkonstruksikan kebulatan-kebulatan demikian yang dialami masa lalu. Dalam penelitian ini teknik wawancara yang peneliti gunakan adalah wawancara mendalam artinya peneliti mengajukan beberapa pertanyaan secara mendalam yang berhubungan dengan fokus permasalahan.

Wawancara dilakukan di lapangan dalam pelaksanaan fase Indonesia PPIK 2014-2015 dan hanya dilakukan kepada tiga orang peserta PPIK 2014-2015 yang diambil dengan pertimbangan keterbatasan waktu.

Teknik Observasi di dalam penelitian kualitatif diklarifikasikan menjadi tiga cara. Pertamapengamat dapat bertindak sebagai partisipan atau non partisipan. Kedua observasi dapat dilakukan secara terus terang atau penyamaran. Ketiga observasi yang menyangkut latar penelitian dan dalam penelitian ini digunakan tehnik observasi yang pertama di mana pengamat bertindak sebagai partisipan. Sutrisno Hadi dalam Andi Prastowo (2012: 220) menerangkan bahwa pengamatan (observasi) merupakan pengamatan dan pencatatan secara sistematik terhadap suatu gejala yang tampak pada objek penelitian.

Observasi yang dilakukan dengan melakukan kunjungan ke Kelurahan Pulau Tidung sehingga menemukan berbagai hasil pengamatan dan dilakukan pencatatan. Observasi dilakukan dengan mengikuti hasil kegiatan-kegiatan yang dilakukan para peserta PPIK 2014-2015 di Kelurahan Pulau Tidung, bergaul dan membaur dengan para warga Kelurahan Pulau Tidung dan melakukan kegiatan pengamatan dalam waktu total kurang lebih seminggu.

Teknik Dokumentasi, digunakan untuk mengumpulkan data dari sumber non-insani, sumber ini terdiri dari dokumen dan rekaman. Rekaman sebagai setiap tulisan atau pernyataan yang dipersiapkan oleh atau untuk individual atau organisasi dengan tujuan membuktikan adanya suatu peristiwa atau memenuhi akuntabilitas. Sedangkan dokumen digunakan untuk mengacu atau bukan selain rekaman, yaitu tidak dipersiapkan secara khusus untuk tujuan tertentu, seperti: surat-surat, buku harian, catatan khusus, foto-foto dan sebagainya.

Hasil temuan memerlukan pembahasan lebih lanjut dan penafsiran lebih dalam untuk menemukan makna di balik fakta. Dalam melakukan pembahasan terhadap temuantemuan penelitian, peneliti harus kembali mencermati secara kritis dan hati-hati terhadap perspektif teoritis yang digunakan.

Menurut Moleong, data penelitian kualitatif tidak berbentuk angka, melainkan narasi, deskripsi, cerita, dokumen tertulis dan tidak tertulis, ataupun bentuk-bentuk data nonangka 
lainnya. Ketika wawancara dan observasi, maka akan didapatkan data mentah yang harus dianalisis. Analisis data ini akan tergantung pada pengetahuan yang dimiliki oleh masingmasing peneliti. Pengetahuan kita nantinya akan menunjuk pada empat arah, yaitu pengetahuan teoretis, pengalaman di lapangan, pengetahuan akan konteks, dan pengetahuan teknik analisis data. (Moleong, 2012: 190)

Penelitian diawali dengan proses pengumpulan data (data collection) yang diperlukan dalam penelitian. Setelah data terkumpul, langkah selanjutnya adalah analisis data. Analisis data dilakukan pada saat pengumpulan data berlangsung dan setelah pengumpulan data selesai dalam periode tertentu.

Aktivitas dalam analisis data kualitatif dilakukan secara interaktif dan berlangsung secara terus menerus sampai tuntas sehingga datanya sudah jenuh. Aktivitas dalam analisis data yaitu reduksi data, penyajian data, dan kesimpulan/verifikasi.

Dalam penelitian ini, peneliti memasuki setting pelaksanaan fase Indonesia PPIK 20142015 di Kelurahan Pulau Tidung sebagai tempat penelitian. Kemudian dalam mereduksi data, peneliti memfokuskan pada 2 pasang peserta dan 1 pasang PS, dengan mengategorikan pada aspek sumber informasi, jenis, dan karakteristik kebutuhan informasi.

Adapun analisis yang digunakan adalah deskriptif kualitatif, baik terhadap motivasi peserta, kondisi objektif komunitas tuan rumah, pemilihan program kerja dan pencapaian tujuan PPIK 2014-2015. Data-data yang dikumpulkan dari mulai proses wawancara, pengamatan dan dokumentasi di proses untuk dilakukan pengolahan.

Analisis data PPIK 2014-2015 yang paling memungkinkan untuk digunakan adalah dengan cara studi kasus. Burhan Bungin menyatakan bahwa studi kasus adalah salah satu strategi dan metode analisis data kualitatif yang menekankan pada kasus-kasus khusus yang terjadi pada objek analisis. Model analisis studi kasus adalah sebagai berikut :

1. Menemukan domain-domain analisis;

2. Domain analisis dipetakan sebagai domain tunggal atau domain ganda;

3. Apabila domain tunggal, maka studi kasus dapat dilakukan dengan mendeskripsikan domain itu berdasarkan fenomena vertikal maupun fenomena horizontal;

4. Apabila domain ganda maka studi kasus dapat dilakukan selain menjelaskan fenomena tunggal, juga menjelaskan hubungan-hubungan antar domain itu. (Bungin, 2011: 237)

Tipe studi kasus yang dapat digunakan dalam penelitian ini adalah tipe studi kasus observasi. Studi kasus observasi adalah menekankan pada penggunaan observasi dalam penelitian untuk menjaring informasi-informasi empiris yang detail dan aktual dari unit analisis penelitian, menyangkut kehidupan individu maupun unit-unit sosial tertentu dalam masyarakat. Metode studi kasus sejalan dengan metode studi penjelasan atau ekplanatoris yang akan digunakan dalam penelitian. Teknik analisis yang mengarah kepada ekplanatoris di mana akan banyak dilakukan analisis sebagai berikut:

1. Menganalisis data yang relevan yang menujukkan motivasi para peserta mengikuti PPIK 2014-2015.

2. Menganalisis sejauh mana pencapaian motivasi peserta PPIK 2014-2015 berhubungan dengan kesuksesan PPIK 2014-2015.

3. Menganalisis faktor-faktor penghambat pencapaian motivasi para peserta dan pencapaian tujuan PPIK 2014-2015.

4. Menganalisis kaitan motivasi pribadi para peserta dengan pencapaian tujuan-tujuan PPIK 2014-2015.

5. Melakukan proses penyesuaian pola untuk membandingkan cara berpikir secara empiris dan logis yang didasarkan pada pola tertentu dengan apa yang ditemukan selama penelitian.

6. Melakukan rantai bukti dengan menganalisis kebutuhan diantara data yang dikumpulkan dalam penelitian studi kasus.

7. Melakukan triangulasi data sehingga data yang didapatkan benar-benar data yang mempunyai keabsahan dan terpercaya.

\section{HASIL DAN PEMBAHASAN}

Program Pertukaran Pemuda IndonesiaKanada 2014-2015 merupakan program pertukaran pemuda negara Indonesia dan Kanada yang dibentuk dan dilaksanakan oleh sebuah lembaga yang bernama Canada World Youth (CWY) dan Kementerian Pemuda dan Olahraga Republik Indonesia. CWY telah bekerja sama dengan Pemerintah Republik Indonesia sejak tahun 1973, dan ini adalah kerja sama terpanjang yang telah dilakukan oleh CWY. Setelah sempat dikelola oleh Departemen Pendidikan dan Kebudayaan (Depdikbud) dan kemudian beberapa tahun oleh Departemen Pendidikan Nasional (Depdiknas), pengemban kerja sama dari pihak Indonesia adalah Kemenpora RI. 
Para peserta yang termasuk dalam kelompok PPIK 2014-2015 di Kelurahan Pulau Tidung ini berasal dari provinsi-provinsi di Indonesia dan provinsi-provinsi atau teritori di Kanada. Mereka terdiri dari 4 (empat) peserta laki-laki dan 5 (lima) peserta perempuan dari Indonesia dan 4 (empat) peserta laki-laki dan 5 (lima) peserta perempuan dari Kanada. Para PS sendiri terdiri dari seorang PS laki-laki dari Indonesia dan seorang PS perempuan dari Kanada.

Berdasarkan informasi yang didapatkan, ditentukan subjek pertama (Subjek 1), yaitu peserta laki-laki dari provinsi Maluku Indonesia, dengan triangulasinya peserta lakilaki dari provinsi Quebec Kanada. Subjek kedua (Subjek 2) adalah seorang peserta perempuan dari provinsi Ontario Kanada, dan triangulasinya seorang peserta perempuan dari provinsi Riau Indonesia. Subjek ketiga (Subjek 3) dari penelitian ini PS atau penyelia program dari Indonesia dan triangulasinya adalah PS dari Kanada.

Tabel 3. Perbandingan Kondisi Subjek

\begin{tabular}{|l|c|c|c|}
\hline Perbandingan & Subjek 1 & Subjek 2 & Subjek 3 \\
\hline Jenis Kelamin & Laki-laki & Perempuan & Laki-laki \\
\hline Usia & 18 & 27 & 28 \\
\hline Pekerjaan & Mahasiswa & $\begin{array}{c}\text { Aktivis } \\
\text { LSM }\end{array}$ & $\begin{array}{c}\text { Project } \\
\text { Supervisor }\end{array}$ \\
\hline Pendidikan & S-1 & S-1 & S-1 \\
\hline Kewarganegaraan & Indonesia & Kanada & Indonesia \\
\hline
\end{tabular}

Tabel 4. Perbandingan Kondisi Triangulasi Subjek

\begin{tabular}{|l|c|c|c|}
\hline \multicolumn{1}{|c|}{ Perbandingan } & $\begin{array}{c}\text { Triangulasi } \\
\text { Subjek 1 }\end{array}$ & $\begin{array}{c}\text { Triangulasi } \\
\text { Subjek 2 }\end{array}$ & $\begin{array}{c}\text { Triangulasi } \\
\text { Subjek 3 }\end{array}$ \\
\hline Jenis Kelamin & Laki-laki & Perempuan & Perempuan \\
\hline Usia & 19 & 21 & 26 \\
\hline Pekerjaan & Mahasiswa & Mahasiswa & $\begin{array}{c}\text { Penyelia } \\
\text { Program }\end{array}$ \\
\hline Pendidikan & S-1 & S-1 & S-1 \\
\hline Kewarganegaraan & Kanada & Indonesia & Kanada \\
\hline
\end{tabular}

Berdasarkan unit-unit makna tiap subjek yang telah disusun, maka dibuat pemetaan konsep dari ketiga subjek. Tabel pemetaan konsep dapat dilihat sebagai berikut.

Tabel 5. Pemetaan Konsep Motivasi Peserta Mengikuti PPIK 2014-2015

\begin{tabular}{|c|l|c|c|c|}
\hline No. & \multicolumn{1}{|c|}{$\begin{array}{l}\text { Motivasi ikut PPIK } \\
\mathbf{2 0 1 4 - 2 0 1 5}\end{array}$} & $\begin{array}{c}\text { Subjek } \\
\mathbf{1}\end{array}$ & $\begin{array}{c}\text { Subjek } \\
\mathbf{2}\end{array}$ & $\begin{array}{c}\text { Subjek } \\
\mathbf{3}\end{array}$ \\
\hline 1. & $\begin{array}{l}\text { Pergi ke dan tinggal di } \\
\text { luar negeri }\end{array}$ & Ya & - & Ya \\
\hline 2. & $\begin{array}{l}\text { Mengembangkan } \\
\text { kemampuan bahasa } \\
\text { Inggris }\end{array}$ & Ya & - & Ya \\
\hline 3. & $\begin{array}{l}\text { Mengenal dan } \\
\text { bersosialisasi dengan } \\
\text { orang berbeda budaya }\end{array}$ & Ya & - & Ya \\
\hline 4. & $\begin{array}{l}\text { Mengembangkan } \\
\text { kepribadian }\end{array}$ & Ya & Ya & - \\
\hline 5. & $\begin{array}{l}\text { Berinteraksi dalam } \\
\text { kelompok }\end{array}$ & Ya & Ya & - \\
\hline
\end{tabular}

\begin{tabular}{|c|l|c|c|c|}
\hline 6. & $\begin{array}{l}\text { Mendapatkan } \\
\text { pengakuan dalam } \\
\text { hidup }\end{array}$ & Tidak & Ya & - \\
\hline 7. & $\begin{array}{l}\text { Membanggakan orang } \\
\text { tua dan keluarga }\end{array}$ & Ya & - & - \\
\hline 8. & $\begin{array}{l}\text { Keluar dari zona } \\
\text { nyaman }\end{array}$ & Ya & Ya & - \\
\hline 9. & $\begin{array}{l}\text { Mencapai kemajuan } \\
\text { baru/diri }\end{array}$ & Ya & Ya & - \\
\hline 10. & $\begin{array}{l}\text { Memberi dampak } \\
\text { kepada orang lain }\end{array}$ & Ya & Ya & - \\
\hline 11. & $\begin{array}{l}\text { Memimpin orang lain } \\
\text { agar mereka dapat } \\
\text { memakai gagasan yang } \\
\text { dimunculkan }\end{array}$ & Ya & Ya & - \\
\hline 12. & $\begin{array}{l}\text { Berinteraksi dengan } \\
\text { orang lain dan } \\
\text { berteman }\end{array}$ & Ya & Ya & - \\
\hline 13. & $\begin{array}{l}\text { Bekerja suka rela di } \\
\text { komunitas luar negeri }\end{array}$ & - & Ya & Ya \\
\hline 14. & $\begin{array}{l}\text { Menerapkan hal yang } \\
\text { sudah dipelajari di } \\
\text { kampus }\end{array}$ & - & Ya & - \\
\hline 15. & Menimba ilmu & - & - & Ya \\
\hline 16. & Membuka wawasan & - & - & Ya \\
\hline 17. & $\begin{array}{l}\text { Menambah kredit } \\
\text { akademik di kampus }\end{array}$ & - & - & Ya \\
\hline Sumber: Data Primer Diolah, 2015 & & & \\
\hline
\end{tabular}

\section{Keterangan:}

Subjek 1 dan Subjek 2 menyatakan motivasi-motivasi mereka bergabung dengan PPIK 2014-2015, sedangkan Subjek 3 mengungkapkan motivasi-motivasi para peserta Indonesia dan Kanada dalam mengikuti PPIK 2014-2015 sejauh pengamatannya. Dari tabel di atas terlihat bahwa terdapat persamaanpersamaan motivasi para peserta dalam mengikuti PPIK 2014. Kata 'ya' menunjukkan persetujuan motivasi subjek, sedangkan kata 'tidak' menunjukkan penyangkalan motivasi subjek. Kolom yang kosong menunjukkan bahwa subjek tidak mengatakan apapun tentang hal tersebut.

Tabel 6. Pemetaan Konsep Motivasi Peserta Mengikuti PPIK 2014-2015

\begin{tabular}{|c|c|c|c|c|}
\hline No. & $\begin{array}{l}\text { Motivasi ikut PPIK } \\
\text { 2014-2015 }\end{array}$ & $\begin{array}{c}\text { Subjek } \\
1\end{array}$ & $\begin{array}{c}\text { Subjek } \\
\quad 2\end{array}$ & $\begin{array}{c}\text { Subjek } \\
\mathbf{3} \\
\end{array}$ \\
\hline 1. & $\begin{array}{l}\text { Pergi ke dan tinggal } \\
\text { di luar negeri }\end{array}$ & Ya & - & Ya \\
\hline 2. & $\begin{array}{l}\text { Mengembangkan } \\
\text { kemampuan bahasa } \\
\text { Inggris }\end{array}$ & Ya & - & Ya \\
\hline 3. & $\begin{array}{lr}\text { Mengenal } & \text { dan } \\
\text { bersosialisasi } & \text { dengan } \\
\text { orang } & \text { berbeda } \\
\text { budaya } & \\
\end{array}$ & Ya & - & Ya \\
\hline 4. & $\begin{array}{l}\text { Mengembangkan } \\
\text { kepribadian }\end{array}$ & $\mathrm{Ya}$ & $\mathrm{Ya}$ & - \\
\hline 5. & $\begin{array}{l}\text { Berinteraksi } \\
\text { kelompok }\end{array}$ & $\mathrm{Ya}$ & Ya & - \\
\hline 6. & $\begin{array}{l}\text { Mendapatkan } \\
\text { pengakuan dalam } \\
\text { hidup }\end{array}$ & Tidak & Ya & - \\
\hline 7. & $\begin{array}{l}\text { Membanggakan } \\
\text { orang tua dan } \\
\text { keluarga }\end{array}$ & $\mathrm{Ya}$ & - & - \\
\hline 8. & $\begin{array}{lll}\begin{array}{l}\text { Keluar } \\
\text { nyaman }\end{array} & \text { dari } & \text { zona } \\
\end{array}$ & Ya & $\mathrm{Ya}$ & - \\
\hline 9. & $\begin{array}{l}\text { Mencapai kemajuan } \\
\text { baru/diri }\end{array}$ & Ya & Ya & - \\
\hline 10. & $\begin{array}{l}\text { Memberi dampak } \\
\text { kepada orang lain }\end{array}$ & Ya & Ya & - \\
\hline 11. & Memimpin orang lain & $\mathrm{Ya}$ & $\mathrm{Ya}$ & - \\
\hline
\end{tabular}




\begin{tabular}{|c|c|c|c|c|}
\hline & $\begin{array}{l}\text { agar mereka dapat } \\
\text { memakai gagasan } \\
\text { yang dimunculkan }\end{array}$ & & & \\
\hline 12. & $\begin{array}{l}\text { Berinteraksi r dengan } \\
\text { orang lain dan } \\
\text { berteman }\end{array}$ & Ya & $\mathrm{Ya}$ & - \\
\hline 13. & $\begin{array}{l}\text { Bekerja suka rela di } \\
\text { komunitas luar negeri }\end{array}$ & - & $\mathrm{Ya}$ & Ya \\
\hline 14. & $\begin{array}{l}\text { Menerapkan hal yang } \\
\text { sudah dipelajari di } \\
\text { kampus }\end{array}$ & - & $\mathrm{Ya}$ & - \\
\hline 15. & Menimba ilmu & - & - & $\mathrm{Ya}$ \\
\hline 16. & Membuka wawasan & - & - & $\mathrm{Ya}$ \\
\hline 17. & $\begin{array}{l}\text { Menambah kredit } \\
\text { akademik di kampus }\end{array}$ & - & - & Ya \\
\hline
\end{tabular}

\section{Keterangan:}

Subjek 1 dan Subjek 2 menyatakan motivasi-motivasi mereka bergabung dengan PPIK 2014-2015, sedangkan Subjek 3 mengungkapkan motivasi-motivasi para peserta Indonesia dan Kanada dalam mengikuti PPIK 2014-2015 sejauh pengamatannya. Dari tabel di atas terlihat bahwa terdapat persamaanpersamaan motivasi para peserta dalam mengikuti PPIK 2014. Kata 'ya' menunjukkan persetujuan motivasi subjek, sedangkan kata 'tidak' menunjukkan penyangkalan motivasi subjek. Kolom yang kosong menunjukkan bahwa subjek tidak mengatakan apapun tentang hal tersebut.

Ditemukan 17 (tujuh belas) motivasi yang berbeda yang dinyatakan oleh Subjek 1, Subjek 2 dan Subjek 3. Setelah ditelaah lebih lanjut ternyata ada 7 (tujuh) motivasi yang sama yang disebutkan baik oleh Subjek 1 dan Subjek 2 . Selain itu ada 3 (tiga) motivasi yang sama yang dinyatakan baik oleh Subjek 1 dan Subjek 3, ditambah dengan 1 (satu) motivasi yang sama yang disebutkan baik oleh Subjek 2 dan Subjek 3.

Tabel 7. Persamaan Motivasi Subjek 1 dan Subjek 2 Dalam Mengikuti PPIK 2014-2015

\begin{tabular}{|c|l|c|c|}
\hline No. & \multicolumn{1}{|c|}{ Motivasi ikut PPIK 2014-2015 } & Subjek 1 & Subjek 2 \\
\hline 1. & Mengembangkan kepribadian & Ya & Ya \\
\hline 2. & Berinteraksi dalam kelompok & Ya & Ya \\
\hline 3. & Keluar dari zona nyaman & Ya & Ya \\
\hline 4. & Mencapai kemajuan baru/diri & Ya & Ya \\
\hline 5. & $\begin{array}{l}\text { Memberi dampak kepada orang } \\
\text { lain }\end{array}$ & Ya & Ya \\
\hline 6. & $\begin{array}{l}\text { Memimpin orang lain agar } \\
\text { mereka dapat memakai gagasan } \\
\text { yang dimunculkan }\end{array}$ & Ya & Ya \\
\hline 7. & $\begin{array}{l}\text { Berinteraksi dengan orang lain } \\
\text { dan berteman }\end{array}$ & Ya & Ya \\
\hline
\end{tabular}

Tabel 8. Persamaan Motivasi Subjek 1 dan Subjek 3 Dalam Mengikuti PPIK 2014-2015

\begin{tabular}{|c|l|c|c|}
\hline No. & \multicolumn{1}{|c|}{$\begin{array}{c}\text { Motivasi ikut PPIK 2014- } \\
\mathbf{2 0 1 5}\end{array}$} & $\begin{array}{c}\text { Subjek } \\
\mathbf{1}\end{array}$ & $\begin{array}{c}\text { Subjek } \\
\mathbf{3}\end{array}$ \\
\hline 1. & $\begin{array}{l}\text { Pergi ke dan tinggal di luar } \\
\text { negeri }\end{array}$ & Ya & Ya \\
\hline 2. & $\begin{array}{l}\text { Mengembangkan kemampuan } \\
\text { bahasa Inggris }\end{array}$ & Ya & Ya \\
\hline
\end{tabular}

\begin{tabular}{|c|l|c|c|}
\hline 3. & $\begin{array}{l}\text { Mengenal dan bersosialisasi } \\
\text { dengan orang berbeda budaya }\end{array}$ & Ya & Ya \\
\hline
\end{tabular}

Tabel 9. Persamaan Motivasi Subjek 2 dan Subjek 3 Dalam Mengikuti PPIK 2014-2015

\begin{tabular}{|c|l|c|c|}
\hline No. & $\begin{array}{c}\text { Motivasi ikut PPIK 2014- } \\
\mathbf{2 0 1 5}\end{array}$ & Subjek 2 & Subjek 3 \\
\hline 1. & $\begin{array}{l}\text { Bekerja suka rela di } \\
\text { komunitas luar negeri }\end{array}$ & Ya & Ya \\
\hline
\end{tabular}

Ditemukan perbedaan-perbedaan motivasi para peserta dalam mengikuti PPIK 2014-2015, dan juga 6 (enam) perbedaan motivasi di antara para individu yang menjadi subjek penelitian. Setelah diteliti lebih lanjut ternyata ada 1 (satu) motivasi yang hanya dinyatakan oleh Subjek 1 . Selain itu ada 2 (dua) motivasi yang hanya dinyatakan oleh Subjek 2, di mana salah satunya ditolak oleh Subjek 1. Terakhir ada 3 (tiga) motivasi yang hanya dinyatakan oleh Subjek 3.Pencapaian motivasi para peserta dapat dilihat dari tabel-tabel berikut ini:

Tabel 10. Perbedaan Motivasi Subjek 1 dengan Subjek 2 dan Subjek 3 Dalam Mengikuti PPIK 2014-2015

\begin{tabular}{|c|l|c|c|c|}
\hline No. & $\begin{array}{l}\text { Motivasi ikut PPIK } \\
\mathbf{2 0 1 4 - 2 0 1 5}\end{array}$ & $\begin{array}{c}\text { Subjek } \\
\mathbf{1}\end{array}$ & $\begin{array}{c}\text { Subjek } \\
\mathbf{2}\end{array}$ & $\begin{array}{c}\text { Subjek } \\
\mathbf{3}\end{array}$ \\
\hline 1. & $\begin{array}{l}\text { Membanggakan } \\
\text { orang tua dan } \\
\text { keluarga }\end{array}$ & Ya & - & - \\
\hline
\end{tabular}

Sumber: Data Primer Diolah, 2015

Tabel 11. Perbedaan Motivasi Subjek 2 dengan Subjek 1 dan Subjek 3 Dalam Mengikuti PPIK 2014-2015

\begin{tabular}{|c|l|c|c|c|}
\hline No. & \multicolumn{1}{|c|}{$\begin{array}{l}\text { Motivasi ikut PPIK } \\
2014-2015\end{array}$} & $\begin{array}{c}\text { Subjek } \\
1\end{array}$ & $\begin{array}{c}\text { Subjek } \\
2\end{array}$ & $\begin{array}{c}\text { Subjek } \\
3\end{array}$ \\
\hline 1. & $\begin{array}{l}\text { Mendapatkan } \\
\text { pengakuan dalam } \\
\text { hidup }\end{array}$ & Tidak & Ya & - \\
\hline 2. & $\begin{array}{l}\text { Menerapkan hal yang } \\
\text { sudah dipelajari di } \\
\text { kampus }\end{array}$ & - & Ya & - \\
\hline
\end{tabular}

Tabel 12. Perbedaan Motivasi Subjek 3 dengan Subjek 1 dan Subjek 2 Dalam Mengikuti PPIK 2014-2015

\begin{tabular}{|c|l|c|c|c|}
\hline No. & \multicolumn{1}{|c|}{ Motivasi ikut } & Subjek & Subjek & Subjek \\
PPIK 2014-2015 & $\mathbf{1}$ & $\mathbf{2}$ & $\mathbf{3}$ \\
\hline 1. & Menimba ilmu & - & - & Ya \\
\hline 2. & Membuka wawasan & - & - & Ya \\
\hline 3. & $\begin{array}{l}\text { Menambah kredit } \\
\text { akademik di kampus }\end{array}$ & - & - & Ya \\
\hline
\end{tabular}

Sumber: Data Primer Diolah, 2015 
Tabel 13. Pencapaian Motivasi Subjek 1

\begin{tabular}{|c|c|c|c|}
\hline No & $\begin{array}{l}\text { Motivasi ikut } \\
\text { PPIK 2014- } \\
2015\end{array}$ & Hasil & Penjelasan \\
\hline 1 & $\begin{array}{l}\text { Pergi ke dan } \\
\text { tinggal di luar } \\
\text { negeri }\end{array}$ & Tercapai & $\begin{array}{l}\text { Keberangkatan ke } \\
\text { dan tinggal di } \\
\text { komunitas Kanada } \\
\text { menbuktikan } \\
\text { pencapaian } \\
\text { motivasi Subjek } 1 .\end{array}$ \\
\hline 2 & $\begin{array}{l}\text { Mengembangka } \\
\mathrm{n} \text { kemampuan } \\
\text { bahasa Inggris }\end{array}$ & Tercapai & $\begin{array}{l}\text { Penggunaan } \\
\text { bahasa Inggris } \\
\text { sebagai bahasa } \\
\text { resmi sehari-hari } \\
\text { selama } \\
\text { pelaksanaan PPIK } \\
2014-2015 \\
\text { menjamin } \\
\text { pengembangan } \\
\text { kemampuan } \\
\text { bahasa Inggris } \\
\text { Subjek 1. }\end{array}$ \\
\hline 3 & $\begin{array}{l}\text { Mengenal dan } \\
\text { bersosialisasi } \\
\text { dengan orang } \\
\text { berbeda budaya }\end{array}$ & Tercapai & $\begin{array}{l}\text { Hidup dan bekerja } \\
\text { bersama pemuda } \\
\text { Kanada dan } \\
\text { pemuda Indonesia } \\
\text { dari provinsi lain } \\
\text { selama } \\
\text { pelaksanaan PPIK } \\
2014-2015 \\
\text { membuat Subjek 1 } \\
\text { lebih mengenal } \\
\text { dan dapat } \\
\text { bersosialisasi. }\end{array}$ \\
\hline 4 & $\begin{array}{l}\text { Mengembangka } \\
\mathrm{n} \text { kepribadian }\end{array}$ & Tercapai & $\begin{array}{l}\text { Tantangan hidup } \\
\text { dan bekerja } \\
\text { bersama orang lain } \\
\text { memberikan } \\
\text { kesempatan bagi } \\
\text { Subjek 1 untuk } \\
\text { mengembangkan } \\
\text { kepribadiannya. }\end{array}$ \\
\hline 5 & $\begin{array}{l}\text { Berinteraksi } \\
\text { dalam kelompok }\end{array}$ & Tercapai & $\begin{array}{l}\text { Dengan hidup } \\
\text { bersama orang lain } \\
\text { selama } \\
\text { pelaksanaan PPIK } \\
2014-2015 \text {, Subjek } \\
1 \text { mendapat } \\
\text { kesempatan untuk } \\
\text { beradaptasi, } \\
\text { bernegosiasi, dan } \\
\text { menyiasati dirinya } \\
\text { agar dapat berjalan } \\
\text { selaras dengan } \\
\text { dinamika } \\
\text { kelompoknya. }\end{array}$ \\
\hline 6 & $\begin{array}{l}\text { Membanggakan } \\
\text { orang tua dan } \\
\text { keluarga }\end{array}$ & Tercapai & \begin{tabular}{l}
\multicolumn{3}{l}{ Keberangkatannya } \\
Subjek 1 ke \\
Kanada bersama \\
PPIK 2014-2015 \\
sudah pasti \\
membanggakan \\
orang tua dan \\
keluarga.
\end{tabular} \\
\hline 7 & $\begin{array}{l}\text { Keluar dari zona } \\
\text { nyaman }\end{array}$ & Tercapai & $\begin{array}{l}\text { Keberhasilan } \\
\text { meninggalkan } \\
\text { rumah dan terpilih } \\
\text { menjadi peserta } \\
\text { PPIK 2014-2015 } \\
\text { sudah } \\
\text { membuktikan } \\
\text { pencapaian } \\
\text { motivasi Subjek } 1 .\end{array}$ \\
\hline
\end{tabular}

\begin{tabular}{|c|c|c|c|}
\hline 8 & $\begin{array}{l}\text { Mencapai } \\
\text { kemajuan } \\
\text { baru/diri }\end{array}$ & Tercapai & $\begin{array}{l}\text { Keberhasilan } \\
\text { meninggalkan } \\
\text { rumah dan terpilih } \\
\text { menjadi peserta } \\
\text { PPIK 2014-2015 } \\
\text { sudah } \\
\text { membuktikan } \\
\text { pencapaian } \\
\text { motivasi Subjek } 1 .\end{array}$ \\
\hline 9 & $\begin{array}{l}\text { Memberi } \\
\text { dampak kepada } \\
\text { orang lain }\end{array}$ & $\begin{array}{l}\text { Belum } \\
\text { Tercapai }\end{array}$ & $\begin{array}{l}\text { Sebelum Subjek } 1 \\
\text { membuktikan } \\
\text { kontribusinya } \\
\text { kepada masyarakat } \\
\text { sekitarnya setelah } \\
\text { kembali ke } \\
\text { komunitas aslinya, } \\
\text { motivasi ini belum } \\
\text { sepenuhnya } \\
\text { tercapai. }\end{array}$ \\
\hline 10 & $\begin{array}{l}\text { Memimpin } \\
\text { orang lain agar } \\
\text { mereka dapat } \\
\text { memakai } \\
\text { gagasan yang } \\
\text { dimunculkan }\end{array}$ & $\mathrm{Ya}$ & $\begin{array}{l}\text { Cara para PS PPIK } \\
2014-2015 \\
\text { memberikan } \\
\text { kesempatan pada } \\
\text { setiap peserta } \\
\text { untuk bebas } \\
\text { mengemukakan } \\
\text { ide dan } \\
\text { mencalonkan diri } \\
\text { untuk memimpin } \\
\text { kelompok dalam } \\
\text { kegiatan berujung } \\
\text { pada pencapaian } \\
\text { motivasi Subjek } 1 .\end{array}$ \\
\hline 11 & $\begin{array}{l}\text { Berinteraksi } \\
\text { dengan orang } \\
\text { lain dan } \\
\text { berteman }\end{array}$ & $\mathrm{Ya}$ & $\begin{array}{lr}\text { Hidup dan } & \text { bekerja } \\
\text { dengan } & \text { orang- } \\
\text { orang di } & \text { luar } \\
\text { keluarganya } & \\
\text { sendiri } & \\
\text { memberikan } & \\
\text { kesempatan } & \text { bagi } \\
\text { Subjek 1 untuk } \\
\text { mencapai } & \\
\text { motivasinya. } & \\
\end{array}$ \\
\hline
\end{tabular}

Tabel 14. Pencapaian Motivasi Subjek 2

\begin{tabular}{|c|c|c|c|}
\hline No & $\begin{array}{c}\text { Motivasi ikut } \\
\text { PPIK 2014-2015 }\end{array}$ & Hasil & Penjelasan \\
\hline 1 & $\begin{array}{l}\text { Mengembangkan } \\
\text { kepribadian }\end{array}$ & Tercapai & $\begin{array}{l}\text { Tantangan hidup } \\
\text { dan bekerja } \\
\text { bersama orang } \\
\text { lain di luar negeri } \\
\text { memberikan } \\
\text { kesempatan bagi } \\
\text { Subjek } 2 \text { untuk } \\
\text { mengembangkan } \\
\text { kepribadiannya. }\end{array}$ \\
\hline 2 & $\begin{array}{l}\text { Berinteraksi } \\
\text { dalam kelompok }\end{array}$ & Tercapai & 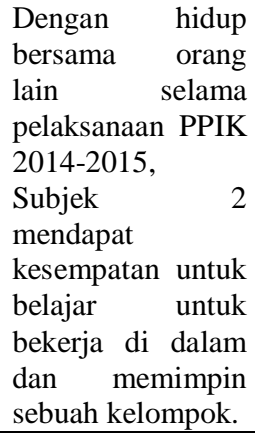 \\
\hline 3 & $\begin{array}{l}\text { Mendapatkan } \\
\text { pengakuan } \\
\text { dalam hidup }\end{array}$ & Tercapai & \begin{tabular}{lr}
\multicolumn{2}{l}{ Hidup dan bekerja } \\
bersama pemuda \\
Kanada r dan \\
pemuda Indonesia
\end{tabular} \\
\hline
\end{tabular}




\begin{tabular}{|c|c|c|c|}
\hline & & & $\begin{array}{l}\text { dari provinsi lain } \\
\text { selama } \\
\text { pelaksanaan PPIK } \\
2014-2015 \\
\text { membuat Subjek } 2 \\
\text { lebih sadar bahwa } \\
\text { pengakuan dari } \\
\text { lingkungan itu } \\
\text { sangat penting. }\end{array}$ \\
\hline 4 & $\begin{array}{l}\text { Keluar dari zona } \\
\text { nyaman }\end{array}$ & Tercapai & $\begin{array}{l}\text { Keputusannya } \\
\text { untuk pergi dari } \\
\text { rumah dan } \\
\text { bergabung dengan } \\
\text { PPIK 2014-2015 } \\
\text { membuat Subjek 2 } \\
\text { dapat mencapai } \\
\text { motivasinya } \\
\text { keluar dari } \\
\text { kenyamanan } \\
\text { kehidupannya } \\
\text { sehari-hari. }\end{array}$ \\
\hline 5 & $\begin{array}{l}\text { Mencapai } \\
\text { kemajuan } \\
\text { baru/diri }\end{array}$ & Tercapai & $\begin{array}{l}\text { Keberangkatannya } \\
\text { Subjek } 2 \text { ke } \\
\text { Indonesia bersama } \\
\text { PPIK 2014-2015 } \\
\text { sudah pasti } \\
\text { memberinya } \\
\text { kesempatan untuk } \\
\text { mencoba hal-hal } \\
\text { baru dan } \\
\text { bepergian yang } \\
\text { membuatnya } \\
\text { mencapai } \\
\text { motivasinya } \\
\text { dalam hal ini. }\end{array}$ \\
\hline 6 & $\begin{array}{l}\text { Memberi } \\
\text { dampak kepada } \\
\text { orang lain }\end{array}$ & Tercapai & $\begin{array}{l}\text { Kebersamaan } \\
\text { dengan para } \\
\text { peserta lain serta } \\
\text { warga komunitas } \\
\text { tuan rumah PPIK } \\
\text { 2014-2015 } \\
\text { memberikan } \\
\text { kesempatan untuk } \\
\text { Subjek } 2 \text { untuk } \\
\text { memberikan } \\
\text { dampak kepada } \\
\text { orang lain. }\end{array}$ \\
\hline 7 & $\begin{array}{l}\text { Memimpin } \\
\text { orang lain agar } \\
\text { mereka dapat } \\
\text { memakai } \\
\text { gagasan yang } \\
\text { dimunculkan }\end{array}$ & Tercapai & $\begin{array}{l}\text { Dalam PPIK, } \\
\text { setiap peserta } \\
\text { dituntut untuk } \\
\text { mampu } \\
\text { mengemukakan } \\
\text { ide dan memimpin } \\
\text { orang lain dalam } \\
\text { melaksanakan } \\
\text { idenya tersebut. } \\
\text { Ini yang } \\
\text { membawa } \\
\text { keberhasilan } \\
\text { pencapaian } \\
\text { motivasi Subjek } 2 .\end{array}$ \\
\hline 8 & $\begin{array}{l}\text { Berinteraksi } \\
\text { dengan orang } \\
\text { lain dan } \\
\text { berteman }\end{array}$ & $\begin{array}{l}\text { Belum } \\
\text { Tercapai }\end{array}$ & $\begin{array}{l}\text { Subjek } \\
\text { mengatakan } \\
\text { bahwa motivasi } \\
\text { bergabung PPIK } \\
2014-2015 \text { adalah } \\
\text { untuk } \\
\text { perkembangan } \\
\text { pribadinya. } \\
\text { Namun karena } \\
\text { dalam } \\
\text { pelaksanaannya } \\
\text { dia selalu berada } \\
\text { bersama orang } \\
\text { lain, Subjek 2 }\end{array}$ \\
\hline
\end{tabular}

\begin{tabular}{|c|l|l|l|}
\hline & & $\begin{array}{l}\text { belajar untuk } \\
\text { berinteraksi } \\
\text { dengan orang lain. }\end{array}$ \\
\hline 9 & $\begin{array}{l}\text { Bekerja suka rela } \\
\text { di komunitas } \\
\text { luar negeri }\end{array}$ & Tercapai & $\begin{array}{l}\text { Keberadaannya di } \\
\text { Pulau Tidung dan } \\
\text { bekerja sebagai } \\
\text { relawan telah } \\
\text { membuatnya } \\
\text { berhasil mencapai } \\
\text { motivasinya. }\end{array}$ \\
\hline 10 & $\begin{array}{l}\text { Menerapkan hal } \\
\text { yang sudah } \\
\text { dipelajari di } \\
\text { kampus }\end{array}$ & Tercapai & $\begin{array}{l}\text { Sebagai seorang } \\
\text { yang mempelajari } \\
\text { ilmu hubungan } \\
\text { internasional di } \\
\text { masa kuliahnya di } \\
\text { kampus dulu, } \\
\text { Subjek 2 dapat } \\
\text { menerapkan } \\
\text { pengetahuannya } \\
\text { tentang kerjasama } \\
\text { pembangunan } \\
\text { internasional. }\end{array}$ \\
\hline
\end{tabular}

Sumber: Data Primer Diolah, 2015

Dari penjabaran di atas dapat dilihat bahwa ada beberapa motivasi para peserta yang belum tercapai. Kegagalan pencapaian ini disebabkan oleh beberapa faktor penghambat. Pemulangan peserta ke daerah asal sebelum program berakhir adalah salah satunya, yang disebabkan oleh sakit yang berkepanjangan dan pelanggaran serius atas tata tertib pelaksanaan PPIK 2014-2015.

Penghambat kedua adalah sifat program ini yang kaku yang sedikit mempengaruhi dan menghambat pencapaian motivasi peserta. Beberapa contoh dari kekakuan program ini adalah waktu yang sempit, larangan untuk bepergian ke luar komunitas tuan rumah, dan pembatasan gerak para peserta lainnya. Para peserta tahu dan mengerti bahwa peraturanperaturan tersebut diterapkan untuk menjamin keselamatan para peserta sendiri.

Berbicara tentang kaitan motivasi pribadi para peserta dengan pencapaian tujuan-tujuan PPIK 2014-2015, kita harus melihat PPIK 2014-2015 ini secara lebih mendalam. Program pertukaran pemuda yang diselenggarakan oleh kedua negara ini mempunyai delapan pilar utama, yaitu: (1) sistem kemitraan; (2) kelompok; (3) hidup bersama keluarga; (4) pengalaman kerja; (5) kegiatan edukatif; (6) proses pembelajaran; (7) sebelum program; dan (8) sesudah program. Di dalam delapan pilar utama inilah PPIK 2014-2015 dilaksanakan. 


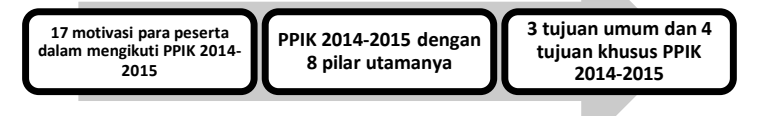

Gambar 2. Kaitan Motivasi-motivasi Para Peserta dengan Pencapaian Tujuan-tujuan PPIK 2014-2015

Data hasil penelitian tentang motivasi pribadi para peserta dalam mengikuti PPIK 2014-2015 dan keterkaitannya dengan proposisi penelitian dapat dilihat sebagai berikut:

Proposisi 1: Motivasi pribadi para peserta dalam mengikuti PPIK 2014-2015 menjelaskan faktor-faktor yang membantu pencapaian tujuan-tujuan PPIK 2014-2015

Tabel 15. Keterkaitan Data Hasil Penelitian dengan Proposisi 1

\begin{tabular}{|l|l|l|l|}
\hline \multicolumn{1}{|c|}{ Data } & \multicolumn{1}{c|}{ Ukuran } & \multicolumn{1}{c|}{ Kondisi } & \multicolumn{1}{c|}{ Analisis } \\
\hline Data tentang & Tanggapan & Motivasi- & Motivasi- \\
motivasi para & subjek & motivasi & motivasi \\
peserta dalam & penelitian & subjek & subjek \\
mengikuti & tentang & penelitian & penelitian \\
PPIK 2014- & motivasi & dalam & sangat \\
2015 & mereka & mengikuti & bervariasi \\
menggunakan & dalam & PPIK & \\
Teori-teori & mengikuti & 2014-2105 & \\
motivasi dari & PPIK & membantu & \\
Maslow, & 2014-2015 & pencapaian & \\
Alderfer, & & tujuan- & \\
Herzberg, & & tujuan & \\
McClelland, & & PPIK & \\
serta Teori Y & & $2014-2015$ & \\
dari Douglas & & & \\
McGregor dan & & & \\
Self & & \\
Determination & & & \\
Theory dari & & \\
Daniel Pink & & \\
sebagai teori- & \\
teori utama. & & & \\
Sumber: Data Primer Diolah, 2015 & \\
\hline
\end{tabular}

Data hasil penelitian tentang pencapaian motivasi para peserta dalam mengikuti PPIK 2014-2015 dan keterkaitannya dengan proposisi penelitian dapat dilihat sebagai berikut:

Proposisi 2: Pencapaian motivasi para peserta PPIK 2014-2015 berhubungan dengan kesuksesan PPIK 2014-2015
Tabel 16. Keterkaitan Data Hasil Penelitian dengan Proposisi 2

\begin{tabular}{|l|l|l|l|}
\hline \multicolumn{1}{|c|}{ Data } & \multicolumn{1}{c|}{ Ukuran } & \multicolumn{1}{c|}{ Kondisi } & \multicolumn{1}{c|}{ Analisis } \\
\hline Data tentang & Tanggapan & Pencapaian & Pencapaian \\
motivasi para & subjek & motivasi & motivasi \\
peserta dalam & penelitian & subjek & subjek \\
mengikuti & tentang & penelitian & penelitian \\
PPIK 2014- & pencapaian & dalam & sebagian \\
2015 & motivasi & mengikuti & sudah \\
menggunakan & mereka & PPIK 2014- & maksimal \\
Teori-teori & dalam & 2105 & sebagian \\
motivasi dari & mengikuti & berhubungan & belum \\
Maslow, & PPIK 2014- & dengan & maksimal \\
Alderfer, & 2015 & kesuksesan & \\
Herzberg, & & PPIK 2014- & \\
McClelland, & & 2015 & \\
serta Teori Y & & & \\
dari Douglas & & & \\
McGregor dan & & & \\
Self & & & \\
Determination & & & \\
Theory dari & & \\
Daniel Pink & & \\
sebagai teori- & \\
teori utama. & & & \\
Sumber: Data Primer Diolah, 2015 & \\
\hline
\end{tabular}

Data hasil penelitian tentang faktor-faktor yang menyebabkan motivasi pribadi para peserta dan tujuan-tujuan PPIK 2014-2015 belum tercapai dan keterkaitannya dengan proposisi penelitian dapat dilihat sebagai berikut:

Proposisi 3: Faktor-faktor penghambat pencapaian motivasi para peserta dan pencapaian tujuan PPIK 2014-2015 menjelaskan penyebab belum tercapainya motivasi para peserta dan pencapaian tujuantujuan PPIK 2014-2015

Tabel 17. Keterkaitan Data Hasil Penelitian dengan Proposisi 3

\begin{tabular}{|l|l|l|l|}
\hline \multicolumn{1}{|c|}{ Data } & \multicolumn{1}{c|}{ Ukuran } & \multicolumn{1}{c|}{ Kondisi } & \multicolumn{1}{c|}{ Analisis } \\
\hline Data tentang & Tanggapan & Faktor- & Faktor- \\
faktor-faktor & subjek & faktor & faktor \\
penghambat & penelitian & penghambat & penghamba \\
pencapaian & tentang & pencapaian & t \\
motivasi para & faktor- & motivasi & pencapaian \\
peserta dan & faktor & subjek & motivasi \\
pencapaian & penghamba & penelitian & subjek \\
tujuan PPIK & t & dalam & penelitian \\
2014-2015 & pencapaian & mengikuti & dan juga \\
menggunaka & motivasi & PPIK 2014- & penghamba \\
n teori & mereka & 2105 juga & t tujuan- \\
efektivitas & dalam & menghamba & tujuan \\
dari & mengikuti & t & PPIK \\
Emerson, & PPIK & pencapaian & 2014-2015 \\
Siagian, dan & 2014-2015. & tujuan- & berasal dari \\
Steers & & tujuan PPIK & internal \\
\multicolumn{2}{|l|}{} & 2014-2015. & dan \\
\hline & & & eksternal \\
Sumber: Data Primer Diolah, 2015 & subjek \\
\hline
\end{tabular}

Data hasil penelitian tentang kaitan motivasi pribadi para peserta dengan pencapaian tujuantujuan PPIK 2014-2015 dan keterkaitannya 
dengan proposisi penelitian dapat dilihat sebagai berikut:

Proposisi 4: Terdapat kaitan motivasi pribadi para peserta dengan pencapaian tujuantujuan PPIK 2014-2015

\section{Tabel 18. Keterkaitan Data Hasil Penelitian} dengan Proposisi 4

\begin{tabular}{|l|l|l|l|}
\hline \multicolumn{1}{|c|}{ Data } & \multicolumn{1}{|c|}{ Ukuran } & \multicolumn{1}{c|}{ Kondisi } & \multicolumn{1}{c|}{ Analisis } \\
\hline Data & Tanggapan & Motivasi & Motivasi \\
tentang & subjek & subjek & subjek \\
motivasi & penelitian & penelitian & penelitian \\
para & tentang & dalam & yang \\
peserta & mereka dalam & mengikuti & disalurkan \\
dan & mengikuti & PPIK & lewat \\
delapan & PPIK 2014- & 2014-2105 & delapan \\
pilar & 2015 dan & disalurkan & pilar PPIK \\
PPIK & penyalurannya & lewat & 2014-2015 \\
2014- & lewat delapan & delapan & berkaitan \\
2015 & pilar PPIK & pilar PPIK & dengan \\
serta & 2014-2015 & 2014-2015 & pencapaian \\
tujuan- & yang bermuara & untuk & tujuan- \\
tujuan- & pada tujuan- & mencapai & tujuan \\
tujuan & tujuan PPIK & tujuan & PPIK 2014- \\
PPIK & $2014-2015$ & PPIK & 2015. \\
$2014-$ & & $2014-$ & \\
2015 & & 2015. & \\
\hline
\end{tabular}

Sumber: Data Primer Diolah, 2015

Pada bagian-bagian di disebutkan dan dijelaskan secara teoretis semua motivasi para peserta dalam mengikuti PPIK 2014-2015. Di dalam bagian terakhir pembahasan ini diinterpretasikan secara teoretis kaitan motivasi pribadi para peserta dengan pencapai tujuantujuan PPIK 2014-2015. Tabel-tabel berikut akan menunjukkan kaitan di antara mereka.

Tabel 19. Motivasi Para Peserta dalam Mengikuti PPIK 2014-2015

\begin{tabular}{|c|l|}
\hline No. & \multicolumn{1}{|c|}{ Motivasi ikut PPIK 2014-2015 } \\
\hline 1. & Pergi ke dan tinggal di luar negeri \\
\hline 2. & Mengembangkan kemampuan bahasa Inggris \\
\hline 3. & $\begin{array}{l}\text { Mengenal dan bersosialisasi dengan orang } \\
\text { berbeda budaya }\end{array}$ \\
\hline 4. & Mengembangkan kepribadian \\
\hline 5. & Berinteraksi dalam kelompok \\
\hline 6. & Mendapatkan pengakuan dalam hidup \\
\hline 7. & Membanggakan orang tua dan keluarga \\
\hline 8. & Keluar dari zona nyaman \\
\hline 9. & Mencapai kemajuan baru/diri \\
\hline 10. & Memberi dampak kepada orang lain \\
\hline 11. & $\begin{array}{l}\text { Memimpin orang lain agar mereka dapat } \\
\text { memakai gagasan yang dimunculkan }\end{array}$ \\
\hline 12. & Berinteraksi dengan orang lain dan berteman \\
\hline 13. & Bekerja suka rela di komunitas luar negeri \\
\hline 14. & Menerapkan hal yang sudah dipelajari di kampus \\
\hline 15. & Menimba ilmu \\
\hline 16. & Membuka wawasan \\
\hline 17. & Menambah kredit akademik di kampus \\
\hline Sub
\end{tabular}

Sumber: Data Primer Diolah, 2015
Tabel 20. Delapan Pilar PPIK 2014-2015

\begin{tabular}{|c|l|}
\hline No. & \multicolumn{1}{|c|}{ Delapan Pilar PPIK 2014-2015 } \\
\hline 1. & The counterpart system (sistem kemitraan) \\
\hline 2. & The team (kelompok) \\
\hline 3. & Family living (hidup bersama keluarga) \\
\hline 4. & Work experience (pengalaman kerja) \\
\hline 5. & Educational activities (kegiatan edukatif) \\
\hline 6. & The Learning process (proses pembelajaran) \\
\hline 7. & Before the program (sebelum program) \\
\hline 8. & After the program (sesudah program) \\
\hline \\
Sumber: Protocol Agreement between Canada World Youth and \\
Ministry of Youth and Sports of the Republic of Indonesia. 2009.
\end{tabular}

Tabel 21. Tujuan-tujuan Umum dan Khusus PPIK 2014-2015

\begin{tabular}{|c|c|}
\hline No. & $\begin{array}{c}\text { Tujuan-tujuan Umum } \\
\text { Program Pertukaran Pemuda Indonesia- } \\
\text { Kanada 2014-2015 }\end{array}$ \\
\hline 1. & $\begin{array}{l}\text { Memupuk rasa persaudaraan dan saling } \\
\text { pengertian antarpemuda Indonesia dan Kanada } \\
\text { dalam rangka mendorong terciptanya } \\
\text { perdamaian dunia. }\end{array}$ \\
\hline 2. & $\begin{array}{l}\text { Memahami tanggung jawab dan meningkatkan } \\
\text { kemitraan untuk pembangunan nasional dan } \\
\text { internasional. }\end{array}$ \\
\hline 3. & $\begin{array}{l}\text { Memberikan bekal ketrampilan, sehingga para } \\
\text { pemuda mampu berpartisipasi secara lebih aktif } \\
\text { dan efektif dalam pembangunan masyarakat } \\
\text { pedesaan. }\end{array}$ \\
\hline No. & $\begin{array}{c}\text { Tujuan-tujuan Khusus } \\
\text { Program Pertukaran Pemuda Indonesia- } \\
\text { Kanada 2014-2015 }\end{array}$ \\
\hline 1. & $\begin{array}{l}\text { Memberikan perspektif pemikiran dan wawasan } \\
\text { baru dalam memajukan kegiatan kepemudaan. }\end{array}$ \\
\hline 2. & $\begin{array}{l}\text { Memperluas dan memperkuat kerjasama antara } \\
\text { kedua negara dalam memajukan kedua bangsa } \\
\text { dan negara. }\end{array}$ \\
\hline 3. & $\begin{array}{l}\text { Meningkatkan aktivitas kepemudaan yang } \\
\text { memberikan makna dan nilai tambah bagi } \\
\text { kemandirian, kreativitas, wawasan kebangsaan } \\
\text { pemuda. }\end{array}$ \\
\hline 4. & $\begin{array}{l}\text { Melakukan pemberdayaan masyarakat } \\
\text { khususnya pemuda melalui kegiatan pendidikan, } \\
\text { kesehatan, pelestarian lingkungan hidup, dan } \\
\text { kewirausahaan. }\end{array}$ \\
\hline
\end{tabular}

Kaitan antara motivasi-motivasi para peserta dan pencapaian tujuan PPIK 2014-2015 dapat dilihat di penyaluran motivasi-motivasi para peserta lewat delapan pilar PPIK sampai ke tujuan-tujuan PPIK 2014-2015 seperti dalam gambar di halaman berikut ini. 


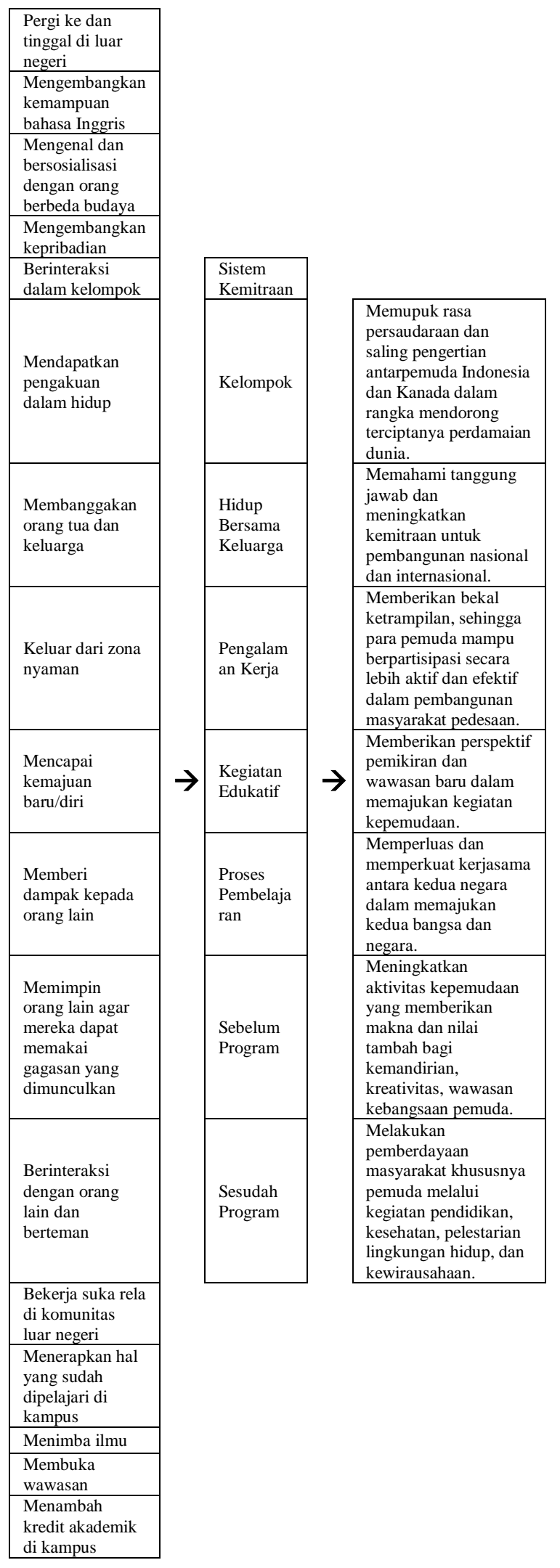

Gambar 3. Penyaluran Motivasi-motivasi Para Peserta lewat Delapan Pilar PPIK 2014-2015 dan Tujuan-tujuan PPIK 2014-2015

Berdasarkan penjabaran di atas ini, dapat disimpulkan bahwa terdapat kaitan antara motivasi para peserta dalam mengikuti PPIK 2014-2015 dengan pencapaian tujuan-tujuan penyelenggaraan PPIK 2014-2015. Hal ini dimungkinkan dengan keberadaan delapan pilar
PPIK 2014-2015, yang menjadi penyaluran motivasi para peserta.

PPIK 2014-2015 sebagai suatu program berjalan dengan efektif karena tujuan-tujuan program ini bisa tercapai melalui pemanfaatan sumber daya yang dimiliki secara efisien, ditinjau dari sisi masukan (motivasi para peserta ikut PPIK 2014-2015), proses (delapan pilar PPIK 2014-2015), maupun keluaran (tujuan-tujuan PPIK 2014-2015). Hal ini sesuai dengan pendapat Steers (1985: 87) yang menyatakan bahwa suatu program dikatakan efektif bila kegiatan tersebut dilaksanakan dengan benar dan memberikan hasil yang bermanfaat. Pelaksanaan PPIK 2014-2015 yang benar dan sesuai dengan prosedur juga menunjukkan bahwa program ini efisien.

\section{KESIMPULAN}

Program Pertukaran Pemuda IndonesiaKanada (PPIK) 2014-2015 merupakan program pertukaran pemuda antarnegara yang dibentuk oleh Kementerian Pemuda dan Olahraga Republik Indonesia (Kemenpora RI) dan Canada World Youth (CWY), sebuah lembaga swadaya masyarakat internasional Kanada. Program pertukaran pemuda antarnegara ini dibentuk dengan tujuan utama memberikan kesempatan bagi generasi muda Indonesia dan Kanada untuk mengembangkan diri dan memaksimalkan segala potensi yang dimilikinya untuk kemajuan mereka di kemudian hari dan pada gilirannya kesuksesan kedua bangsa di masa depan. Pencapaian tujuan PPIK 2014-2015 tentu tidak terlepas dari faktor-faktor pendukung pelaksanaan program di lapangan. Salah satu faktor pendukung pendukung pelaksanaan program di lapangan adalah motivasi para pesertanya.

Para peserta memiliki motivasi-motivasi yang berbeda dalam mengikuti PPIK 20142015. Motivasi-motivasi mereka pada dasarnya adalah ingin untuk mengembangkan segala potensi diri yang mereka miliki lewat pengabdian diri di komunitas Kanada dan Indonesia.

Hasil penelitian lapangan melalui wawancara dan observasi menunjukkan bahwa motivasi-motivasi para peserta dalam mengikuti PPIK 2014-2015 ada yang sama dan ada pula yang berbeda. Hal ini dapat dilihat dari jawaban-jawaban para subjek penelitian dan para triangulasinya.

Hasil penelitian juga menunjukkan bahwa terdapat hal-hal yang menghambat pencapaian motivasi para peserta serta tujuan PPIK 20142015. Penghambat pencapaian motivasi para 
peserta antara lain adalah isu kesehatan dan juga peraturan-peraturan PPIK 2014-2015 yang mereka rasa kurang lentur.

Kaitan antara motivasi para peserta PPIK 2014-2015 dengan pencapaian tujuan-tujuan PPIK 2014-2017 adalah ketika usaha-usaha yang dilakukan oleh para peserta untuk mencapai motivasinya dalam mengikuti PPIK 2014-2015 itu berjalan di koridor pelaksanaan program yang sudah dirancang oleh Kemenpora RI dan CWY. Kemenpora RI dan CWY merancang PPIK 2014-2015 lengkap dengan petunjuk pelaksanaannya serta dilengkapi dengan penjelasan tentang tujuantujuan yang hendak dicapai.

\section{REFERENSI}

\section{Buku-buku:}

Bohlander, George and Scott Snell. 2012. Principles of Human Resource Management. 11th edition.Cengage Learning

Handoko, T. Hani. 2009. Manajemen. Cetakan ke-18. BPFW Yogyakarta.

Mondy, Wayne. 2008. Human Resource Management. Terjemahan Bayu Airlangga. Penerbit Erlangga Jakarta.

Moleong, Lexy. 2012. Metodologi Penelitian Kualitatif. Edisi Revisi. PT Remaja Rosdakarya Bandung. Bandung

Pink, Daniel H. 2009. Drive, the Surprising Truth about What Motivates Us. Penguin Books Ltd. New York.

Poerwandari, E. Kristi. 2011. Penelitian Kualitatif untuk Penelitian Perilaku Manusia. Jakarta: Lembaga Pengembangan Sarana Pengukuran dan
Pendidikan Psikologi

(LPSP3)

Universitas Indonesia.

Prastowo, Andi. 2012. Metode Penelitian Kualitatif dalam Perspektif Rancangan Penelitian. Ar - Ruzz Media. Yogyakarta.

\section{Situs Internet:}

Anonim $^{1}$, 2014. Canada: Definition of Youth http://www.youthpolicy.org/factsheets/co untry/canada. Diakses Jumat 6 Juni 2014 jam 09.09 WIB

Anonim $^{2}, 2014 . \quad$ Canadian Heritage/ Patrimoine Canadien. http://www.pch.gc.ca. Diakses Jumat 6 Juni 2014 jam 08.15 WIB

Anonim $^{3}, 2014$ Services for Youth. http://www.youth.gc.ca. Diakses Sabtu 14 Juni 2014 jam 10.20 WIB

Anonim $^{4}, 2014$ Service Canada. People serving people http://www.servicecanada.gc.ca. Diakses Sabtu 14 Juni 2014 jam 10.20 WIB

Anonim $^{5}, 2014$ Theory $\mathrm{X}$ and Theory Y. http://en.wikipedia.org/wiki/Theory_X_a nd_Theory_Y. Diakses Selasa 21 Januari 2014 pukul 06.00 WIB

\section{Publikasi Lain:}

Protocol Agreement between Canada World Youth and The Deputy of Youth Empowerment of the State Ministry of Youth and Sports Affairs Republic of Indonesia. July 2009.

University of New South Wales (UNSW). 2014. Outbound Exchange Guide. Australia. UNSW 